Research Article

\title{
The earthquake awareness levels of undergraduate students
}

\section{Erol Sözen}

Duzce University, Faculty of Education, Turkey

\begin{abstract}
Natural disasters cause serious effects on economic, social and sociological areas in Turkey. Earthquakes are one of the major natural disasters in Turkey. They affect social and economic life and education negatively. The more preparedness and awareness are provided against natural disasters, the safer society will be. This study was carried out in order to determine the views of undergraduate students about earthquake awareness attitudes and to examine them in terms of various variables. The research was conducted as a screening design from quantitative research models. In the study, a scale was applied as a data collection tool. The study group of the research consists of 619 undergraduate students studying at undergraduate level in various faculties at Düzce University in the academic year 2018-2019. "Earthquake Awareness Scale", developed by the researcher, was applied to these students. According to the results of the study, there was a significant difference in the effects of earthquake sub-factor of the scale in terms of gender of the students. There was no significant difference between grade levels and earthquake awareness levels of undergraduate students in all sub-factors of the scale. In the effects of earthquake subfactor, a significant difference is seen in earthquake awareness of the students in terms of their residences. No significant difference was found in the other sub-factors of the scale according to the residence. There was no significant difference in the earthquake awareness of the undergraduate students in any subfactors of the earthquake awareness levels according to the number of floors of the students' residences. As a result of the study, it was proposed to organize trainings and conferences on natural disasters, especially earthquakes.
\end{abstract}

Keywords: Earthquake; Geograghy education; Earthquake awareness; Undergraduate students

Article History: Submitted 26 December 2018; Revised 1 June 2019; Published online 8 August 2019

\section{Introduction}

Natural disasters have strong and negative effects on human activities. They cause some serious effects on both economic, social and sociological life in Turkey. Disasters are natural events that cannot be coped with, causing physical, economic and social losses for people, affecting societies by stopping or interrupting normal life and human activities (Akar, 2013; Ergünay, 1996). Natural disasters can be listed as avalanches, floods, landslides, droughts, volcano eruptions, frost, storms, earthquakes and so on (Moe \& Pathranarakul, 2006; Şahin \& Sipahioğlu, 2007). The effects of natural disasters on human life are increasing day by day. The loss of life caused by natural disasters in the world in 2009 was four times higher than in the 1980s. It was determined that 950

Address of Corresponding Author

Erol Sözen, Duzce University, Konuralp Yerleşkesi, 81620, Merkez/Düzce.

$\triangle$ erolsozen@duzce.edu.tr

0000-0002-0522-4527

How to cite: Sözen, E. (2019). The earthquake awareness levels of undergraduate students. Journal of Pedagogical Research, 3(2), 87-101. 
natural disasters occurred in 2010 were much higher than the previous 30-year average (Munich, 2010). Earthquakes are one of the major natural disasters in Turkey. Earthquakes are geological and geomorphological disasters. They are the short-term natural events that take their sources from the Earth's depths and cause sudden vibrations and quakes (Güngördü, 2010; İzbirak, 1991; Şahin \& Sipahioğlu, 2007). According to their character of occurrences, earthquakes can be grouped as tectonic, collapse and volcanic. Among these, tectonic earthquakes have the largest impact area and the greatest intensity (Erinç, 2000; Güngördü, 2010; Ilgar, 2017; Şahin \& Sipahioğlu, 2007). When the tectonic earthquake is compared to others, the earthquake region is much wide than the volcanic earthquakes and its severity and destructiveness are much more effective. The region where the tectonic earthquakes are most common in the world is the Pacific Ocean, also called the Pacific Fire Circle (Doğanay \& Sever, 2016; Güngördü, 2010; Ilgar, 2017). It is followed by an Alpine-Himalayan-Caucasian Belt. Turkey is the second major earthquake zone on the Mediterranean Earthquake Belt (Şahin \& Sipahioğlu, 2007; Yazıcı \& Koca, 2014). In Turkey, compressed by Arab-African plates from the South and Eurasia from the North, there are lots of active faults (Öztürk et al., 2008). In Turkey, North Anatolian Fault (NAF), the East Anatolian Fault (EAF) and West Anatolian Fault (WAF) and their surroundings are areas where the risk of earthquakes is quite high. These fault lines are still very active today. Almost all the earthquakes in Turkey are of tectonic origin and occur mostly in and around these three major earthquakes faults. Therefore, in Turkey, in Aegean Region, Marmara Region, North Anatolia Region, Hatay and its surroundings and Eastern Anatolia Region, lots of earthquakes occur often (Atalay, 1987; Sahin \& Sipahioğlu, 2007; Levy et Solvar, 2000 as cited in Ocalan, 2005). Four major earthquakes occurred in the last century $(1943,1957,1967,1999)$ can be considered disasters in Turkey (TUBITAK, 2001).

Almost $90 \%$ of Turkey, about $90 \%$ of Turkey's population, about $70 \%$ of the urban population, about $90 \%$ of industrial areas and almost $70 \%$ of power plants are in earthquake areas. (Erdik 2002). In the last century, earthquakes occurred in Turkey, according to official figures, almost 100 thousand people have passed away and around 200 thousand people were injured (Taymaz, 2001). Factors such as inappropriate settlement choice, unstudied infrastructure, poor construction stock and disruptions in controls increase disaster losses. Earthquakes can have important effects on population distribution and economic activities (Pelling et al., 2002). 1999 Düzce earthquake is an important experience of this. After 1999 Gölcük and Düzce earthquakes, importance of disaster management activities in Turkey and studies in this area has increased. The Gölcük earthquake caused the death of around 18 thousand people, nearly 50 thousand people were injured and almost 120 thousand people became homeless (Başıüyük, 2004; Erdik et al., 2004). Disaster Management is a concept that emphasizes to prevent disasters and minimize their losses. All institutions and organizations need to put their efforts and resources against disasters to plan and implement what needs to be done (Ergünay, 1996). It is of great importance that the entire society, especially those with high earthquake risk, should be made aware of the disasters and be prepared in this regard.

Earthquakes affect social and economic life and education negatively. Physical environments of education, teachers, students and families may face significant difficulties (Y1ld1z, 2000). Earthquakes adversely affect motivation and success in educational environments (Sert, 2002).

To prepare against earthquakes which have serious effects and damages on Turkey, the importance of educational institutions is indisputable. Disaster training in education institutions, especially earthquake, requires a very serious attitude. If the earthquake training is not carried out correctly and effectively, the lack of information will cause the continuation of traditional views on earthquakes and important mistakes (Ross \& Shuell, 1993; Tsai, 2001). Being aware of the earthquake requires having the right information to create this awareness, as well as having the right attitudes to determine how to act against the earthquake (Demirci \& Yıldırım, 2015). Countries and regions include courses for natural disasters in educational institutions in order to know the natural disaster that they can face and to raise awareness of the society. For example, in 
North America, 41.2\% of colleges and universities have courses on natural disasters. In these courses, more regional examples are given (Cross, 2000, p. 77).

Raising awareness against earthquakes that have serious effects in Turkey and maintaining it is highly important in minimizing the damages of a potential earthquake. By increasing the level of knowledge against natural disasters, societies can be ready against earthquakes with all their institutions before the earthquake happens (Demirci \& Yildırım, 2015). Knowing how to act during and after an earthquake is necessary to reduce potential damage. It is known that earthquakerelated damages are much less in societies that have enough information of the earthquake risk and possible damages of them in comparison with the societies that do not have necessary information (Panic et al., 2013). The more preparedness and awareness are provided against natural disasters, the more secure the society will be. For this reason, educational institutions serve as a bridge between students, families and the society in order to raise awareness and make society ready for natural disasters (Johnston et al., 2011). Therefore, it is very crucial to determine the earthquake awareness of the university students who will create an important workforce of a country in the future. It is very important to enhance the knowledge of university students on natural disasters and especially for earthquake and to plan future studies for students in universities to make this knowledge permanent and practicable. For these reasons, it is important to determine the level of earthquake awareness and point of view of university students to raise awareness against earthquake. This study was carried out in this direction.

When the literature was examined, studies have been conducted on the psychosocial effects and damages of the earthquake (Bozkurt, 1999; Erkan, 2010; Karanc1 et al., 1996; Kasapoğlu \& Ecevit, 2001; Lutgens et al., 2013; Panic et al., 2013). Also there were studies about the relationship between earthquake and education (Demirkaya, 2007a; Demirkaya, 2007b; Erdoğan, 2007; Johnston et al., 2011; Kaya \& Aladă̆, 2017; Kayalı, 2018; Ohnishi \& Mitsuhashi 2013; Öcal, 2005; Öcal, 2005; Özdemir et al, 2001; Panic, Majkic \& Milijanovic, 2013; Sert, 2002; Şimşek, 2007; Tanaka, 2005; Taş, 2003; Vance et al., 1995; Yıld1z, 2000). TUBITAK (2001) conducted an important study in terms of geological examination of alternative settlements. However, this type of study was not seen with undergraduate students.

\subsection{Purpose of the Study}

This study was carried out in order to determine the views of undergraduate students about earthquake awareness and to examine in terms of various variables (gender, class, faculty, residence, the number of floors of the residences and faculties).

\section{Method}

In this section, the research model, study group, data collection tools, data collection and data analysis are emphasized.

\subsection{Research Model}

The research was conducted as a survey research method from quantitative research models. Survey is a group of studies aimed at collecting data to reveal some of the special features (Büyüköztürk et al., 2018). In the study, scale was applied as a data collection tool. In this way, the survey model aims to reveal the situation that is the subject of the study as it is (Ekiz, 2015; Karasar, 2016). This method is a preferred research method in social sciences (Borg \& Gall, 1971). For this reason, this study is an important tool in obtaining statistical data survey (Arseven, 2001) and a scale was prepared for the research. Literature review was done for the prepared scales. While preparing the scale, both geography teachers' and undergraduate students' opinions were taken. In addition, opinions of experts from Karabük and Düzce University were collected for field and statistical studies. 


\subsection{Participants}

The study group of the research consists of 204 (33\%) male and 415 (67\%) female students who were randomly selected among the undergraduate students of Düzce University in the academic year 2018-2019. Demographic data of the study group is given in Table 1. The questionnaire was applied face to face on a voluntary basis. Since volunteering is essential, the results of the surveys can be more realistic (Kerski, 2000). It can be said that students who are interested in natural disasters voluntarily participate and fill the questionnaire, not the ones who feel it as a necessity as the questionnaire has been delivered through an official channel. It has also made it easier for the students to fill in the questionnaire more easily and to make corrections. Since the volunteers participated to the study, it is thought that the data obtained from the participants can be more sincere (Arseven, 2001).

Table 1.

Demographic Data of the Study Group

\begin{tabular}{lcc|lcc}
\hline Gender & $\mathrm{N}$ & $\%$ & Grade & $\mathrm{N}$ & $\%$ \\
\hline Male & 204 & 33 & 1th grade & 63 & 10,2 \\
\hline Female & 415 & 67 & 2nd grade & 255 & 41,2 \\
\hline Total & 619 & 100 & 3th grade & 135 & 21,8 \\
\hline Faculty & $\mathrm{N}$ & $\%$ & 4th grade & 166 & 26,8 \\
\hline Education & 145 & 23,4 & Total & 619 & 100 \\
\hline Business Administration & 69 & 11,1 & Residence & $\mathrm{N}$ & $\%$ \\
\hline Forestry & 81 & 13,1 & Student House & 131 & 21,2 \\
\hline Health & 89 & 14,4 & With Family & 71 & 11,5 \\
\hline Arts and Sciences & 88 & 14,2 & State Dormitory & 371 & 59,9 \\
\hline Theology & 86 & 13,9 & Private Dormiory & 46 & 7,4 \\
\hline Engineering & 61 & 9,9 & Total & 619 & 100 \\
\hline The Number of Floors of the & $\mathrm{N}$ & $\%$ & The Number of Floors of the & $\mathrm{N}$ & $\%$ \\
Residences & 66 & 10,7 & F Storey & 207 & 33,4 \\
\hline 1-2 Storey & 109 & 17,6 & 5 Storey & 246 & 39,7 \\
\hline 3 Storey & 151 & 24,4 & +6 Storey & 166 & 26,9 \\
\hline 4 Storey & 293 & 47,3 & Total & 619 & 100 \\
\hline+5 Storey & 619 & 100 & & & \\
\hline Total & & & &
\end{tabular}

\subsection{Instrument}

A scale titled "Earthquake Awareness Scale" was prepared for the study. The scale was applied to 728 undergraduate students (227 male and 501 female) and reliability studies were conducted. As a result of this preliminary application, the 8 th item, the load value of which is less than ,30, and is insufficient to discriminate, was removed from the questionnaire (Schermelleh-Engel et al., 2004). Earthquake Awareness Scale, which consisted of 20 items at the beginning, was determined as 19 items. As a result of the reliability study, the scale was found to be subsuming under three factors. As a result of this application, the reliability of the scale was ensured. These factors were determined as Distribution of Earthquake Zones, the Effects of Earthquake and Earthquake Education factors. The variance explained by these 3 factors is $61.74 \%$. KMO value of the scale was found to be ,87. As a result of reliability analysis, Cronbach Alpha coefficient of the scale was calculated as ,868. In such scales, the results where KMO results are above 70 are suitable for the application (Arseven, 2001; Büyüköztürk, 2018; Karasar, 2016; Leech, Barrett \& Morgan, 2005; Şencan, 2005; Tavşancil, 2005). In addition, the reliability of the scale was re-established by the CFA study. The lisrel 8.80 program was used for DFA. 


\subsection{Data Analysis}

Statistical analyzes were performed using SPSS 22.0 (Statistical Package for Social Science for Personal Computers). Descriptive statistics for the analysis of the problem sentence and subproblems of the research, t-test for unrelated samples and one-way analysis of variance (ANOVA) for unrelated samples were used. Scheffe Post Hoch test was used for comparisons between groups. The scoring range of Likert-scale survey items is given in Table 2.

Table 2.

Likert items scala

\begin{tabular}{lll}
\hline Totally Disagree & 1 & $1,00-1,80$ \\
\hline Disagree & 2 & $1,81-2,60$ \\
\hline Neutral & 3 & $2,61-3,40$ \\
\hline Katliyorum & 4 & $3,41-4,20$ \\
\hline Totally Agree & 5 & $4,21-5,00$ \\
\hline
\end{tabular}

\section{Results}

\subsection{Findings on the answers of undergraduate students towards Earthquake Awareness Scale}

Table 3 shows the descriptive data of the views of undergraduate students regarding the "distribution of earthquake zones" factor.

Table 3.

Percentage Frequency Analysis of the Responses to the Items in the Distribution of Earthquake Zones

\begin{tabular}{|c|c|c|c|c|c|c|c|c|c|c|c|}
\hline \multirow{3}{*}{ Items } & \multicolumn{10}{|c|}{ Distribution of Earthquake Zones Factor } & \\
\hline & \multicolumn{2}{|c|}{$\begin{array}{c}\text { Totally } \\
\text { Disagree }\end{array}$} & \multicolumn{2}{|c|}{ Disagree } & \multicolumn{2}{|c|}{ Neutral } & \multicolumn{2}{|c|}{ Agree } & \multicolumn{2}{|c|}{ Totally Agree } & \\
\hline & $\mathrm{f}$ & $\%$ & $\mathrm{f}$ & $\%$ & $\mathrm{f}$ & $\%$ & $\mathrm{f}$ & $\%$ & $\mathrm{f}$ & $\%$ & $\bar{X}$ \\
\hline $\begin{array}{l}\text { 1. I have knowledge } \\
\text { about natural disasters } \\
\text { which can occur in my } \\
\text { country. }\end{array}$ & 8 & 1,3 & 31 & 5,0 & 97 & 15,7 & 373 & 60,3 & 110 & 17,8 & 3,88 \\
\hline $\begin{array}{l}\text { 2. I have knowledge } \\
\text { about the most } \\
\text { destructive natural } \\
\text { disasters in my country. } \\
\text { 3. I have knowledge }\end{array}$ & 7 & 1,1 & 46 & 7,4 & 125 & 20,2 & 348 & 56,2 & 93 & 15,0 & 3,76 \\
\hline $\begin{array}{l}\text { about where the fault } \\
\text { lines in my country. } \\
\text { 4. I have knowledge }\end{array}$ & 8 & 1,3 & 43 & 6,9 & 171 & 27,6 & 295 & 47,6 & 102 & 16,5 & 3,71 \\
\hline $\begin{array}{l}\text { about the earthquake } \\
\text { risk of my country. }\end{array}$ & 3 &, 5 & 36 & 5,8 & 109 & 17,6 & 362 & 58,5 & 109 & 17,6 & 3,86 \\
\hline $\begin{array}{l}\text { 5. I have knowledge } \\
\text { about places in a high } \\
\text { risk of earthquakes in } \\
\text { the world. }\end{array}$ & 14 & 2,3 & 100 & 16,2 & 182 & 29,4 & 266 & 42,9 & 57 & 9,2 & 3,40 \\
\hline $\begin{array}{l}\text { 6. I have knowledge } \\
\text { about places in a high } \\
\text { risk of earthquakes in } \\
\text { my country. }\end{array}$ & 5 & ,80 & 31 & 5,0 & 104 & 16,8 & 381 & 61,6 & 98 & 15,8 & 3,86 \\
\hline $\begin{array}{l}\text { 7. I have knowledge } \\
\text { about places with less } \\
\text { earthquake risk in my } \\
\text { country. }\end{array}$ & 11 & 1,8 & 60 & 9,7 & 144 & 23,3 & 308 & 49,8 & 96 & 15,5 & 3,67 \\
\hline & & & & & & & & & & & 3,73 \\
\hline
\end{tabular}


As can be seen in Table 3, the most favorable opinion was: "I have knowledge about natural disasters that can be seen in Turkey" ( $\bar{X}=3.88$ / I agree) and most of them don't answer this item: "I have knowledge about places that are in more earthquake risk in the world." ( $\bar{X}=3.40$ / neutral). The average of the students' views on the distribution of earthquake zones was $(\bar{X}=3.73)$ for "I agree" option. According to the data in this table, it can be said that the awareness level of the undergraduate students regarding the distribution of earthquake zones is high. Table 4 shows the descriptive data of the views of undergraduate students about the "the Effects of Earthquake" factor.

Table 4.

Percentage Frequency Analysis of the Responses to the Items in the Effects of Earthquake Factor of the Scale

\begin{tabular}{|c|c|c|c|c|c|c|c|c|c|c|c|}
\hline \multirow{3}{*}{ Items } & \multicolumn{10}{|c|}{ Effects of Earthquake Factor } & \\
\hline & \multicolumn{2}{|c|}{ Totally Disagree } & \multicolumn{2}{|c|}{ Disagree } & \multicolumn{2}{|c|}{ Neutral } & \multicolumn{2}{|c|}{ Agree } & \multicolumn{2}{|c|}{$\begin{array}{l}\text { Totally } \\
\text { Agree }\end{array}$} & \multirow[b]{2}{*}{$\bar{X}$} \\
\hline & $\mathrm{f}$ & $\%$ & $\mathrm{f}$ & $\%$ & $\mathrm{f}$ & $\%$ & $\mathrm{f}$ & $\%$ & $\mathrm{f}$ & $\%$ & \\
\hline $\begin{array}{l}\text { 8. The city I live in is under } \\
\text { the risk of earthquake. } \\
\text { 9. I have knowledge about } \\
\text { the importance of having } \\
\text { an earthquake emergency } \\
\text { kit before the earthquake. }\end{array}$ & 8 & 1,0 & 38 & 1,5 & 98 & 15,8 & 273 & 44,1 & 202 & 66,9 & 4,00 \\
\hline $\begin{array}{l}\text { 10. I have information } \\
\text { about the importance of } \\
\text { fixing the items on the wall } \\
\text { in case of falling down. }\end{array}$ & 9 & 1,5 & 22 & 3,6 & 73 & 11,8 & 287 & 46,4 & 228 & 36,8 & 4,13 \\
\hline $\begin{array}{l}\text { 11. I have knowledge about } \\
\text { the effects of earthquake on } \\
\text { structures. }\end{array}$ & 3 & ,5 & 31 & 5,0 & 72 & 11,6 & 330 & 53,3 & 183 & 29,6 & 4,06 \\
\hline $\begin{array}{l}\text { 12. I have knowledge about } \\
\text { the material damages of } \\
\text { earthquakes. }\end{array}$ & 4 & 6 & 18 & 2,9 & 49 & 7,9 & 306 & 49,4 & 242 & 39,1 & 4,23 \\
\hline $\begin{array}{l}\text { 13. I have knowledge about } \\
\text { the moral damages of } \\
\text { earthquakes. }\end{array}$ & 3 & ,5 & 18 & 2,9 & 38 & 6,1 & 283 & 45,7 & 277 & 44,7 & 4,31 \\
\hline $\begin{array}{l}\text { 14. I know that being aware } \\
\text { of the earthquake will save } \\
\text { life sometimes. }\end{array}$ & 4 & 6 & 6 & 1,0 & 40 & 6,5 & 201 & 32,5 & 368 & 59,5 & 4,49 \\
\hline & & & Aver & & & & & & & & 4,25 \\
\hline
\end{tabular}

According to Table 4, the most favorable opinion of the students was "The city I live in is at risk of earthquakes" ( $\bar{X}=4.57$ / I totally agree), while the lowest participation was stated for this item: "I have knowledge about the importance of having the earthquake bag before the earthquake " $(\bar{X}=4,00$ / I agree). The average of students' views on Effects of Earthquake was $(\bar{X}=4.25)$ for "I totally agree" option. According to the data in this table, undergraduate students' level of knowledge about the Effects of Earthquake is high. Table 5 shows the descriptive data of the views of undergraduate students regarding the "Earthquake Education" factor.

Table 5 shows that the highest participation was for the "University informs me about the things that should be done in case of earthquake" item $(\bar{X}=2,6=2,64$ / undecided), while the lowest participation was for the "University education makes me aware of natural disasters" item $(\bar{X}=2,74$ / neutral). The average of students' views on Earthquake Education was $(\bar{X}=2.69)$ for "neutral" option. According to the data in this table, it can be said that the undergraduate students find the Earthquake Education inadequate. 
Table 5.

Percentage Frequency Analysis of the Responses to the Items in the Earthquake Education Factor of the Scale

Items

\section{Earthquake Education Factor}

\begin{tabular}{|c|c|c|c|c|c|c|c|c|c|c|c|}
\hline \multirow[t]{2}{*}{ Items } & \multicolumn{2}{|c|}{$\begin{array}{c}\text { Totally } \\
\text { Disagree }\end{array}$} & \multicolumn{2}{|c|}{ Disagree } & \multicolumn{2}{|c|}{ Neutral } & \multicolumn{2}{|c|}{ Agree } & \multicolumn{2}{|c|}{ Totally Agree } & \multirow[b]{2}{*}{$\bar{X}$} \\
\hline & $\mathrm{f}$ & $\%$ & $\mathrm{f}$ & $\%$ & $\mathrm{f}$ & $\%$ & $\mathrm{f}$ & $\%$ & $\mathrm{f}$ & $\%$ & \\
\hline $\begin{array}{l}\text { 15. University education } \\
\text { makes me aware of natural } \\
\text { disasters. }\end{array}$ & 77 & 13,4 & 188 & 34,4 & 201 & 38,1 & 121 & 24,6 & 32 & 7,1 & 2,74 \\
\hline $\begin{array}{l}\text { 16. University education } \\
\text { prepares me for } \\
\text { earthquakes that may occur } \\
\text { in our city. }\end{array}$ & 59 & 11,0 & 211 & 38,6 & 224 & 42,3 & 98 & 19,6 & 27 & 6,1 & 2,71 \\
\hline $\begin{array}{l}\text { 17. Thanks to university } \\
\text { education, I am aware of } \\
\text { what should be done before } \\
\text { the earthquake (being } \\
\text { ready for earthquake). }\end{array}$ & 64 & 11,5 & 195 & 36,4 & 228 & 41,7 & 106 & 22,1 & 26 & 6,0 & 2,73 \\
\hline $\begin{array}{l}\text { 18. University education } \\
\text { informs me about what to } \\
\text { do in case of an earthquake. }\end{array}$ & 82 & 14,5 & 205 & 38,1 & 205 & 37,6 & 106 & 22,5 & 21 & 4,8 & 2,64 \\
\hline $\begin{array}{l}\text { 19. University education } \\
\text { raises awareness about } \\
\text { what can be done after the }\end{array}$ & 82 & 14,7 & 206 & 37,8 & 192 & 36,4 & 111 & 23,4 & 28 & 5,3 & 2,67 \\
\hline & & & & cage & & & & & & & 2,69 \\
\hline
\end{tabular}

When the Table 6 is examined, it is seen that the independent groups $t$ test results show whether the earthquake awareness levels of undergraduate students differ according to the gender. According to the table, there was no significant difference between the gender of the students and the factor of distribution of earthquake zones, which is the first sub-factor of Earthquake Awareness Levels [t $(617)=0.689 ; \mathrm{p}>$.05]. When the effects of earthquake factor, which is the second sub-factor, is examined, it is seen that there is a significant difference in terms of gender of the students $[t(617)=-3,148 ; p<.05]$. When the earthquake education factor, which is the third sub-factor, is examined, there is no significant difference in terms of gender of students $[t(617)=1,026 ; p>$.05]. When the whole scale is examined, it is seen that there is no significant difference between the gender and earthquake knowledge level of the students $[t(617)=-0,515$; $\mathrm{p}>$.05].

Table 6.

Independent groups $t$ test results related to whether earthquake awareness levels of undergraduate students differ according to gender of students

\begin{tabular}{|c|c|c|c|c|c|c|c|}
\hline Variable & Gender & $\mathbf{n}$ & $\bar{X}$ & S & Sd & $t$ & $\mathbf{p}$ \\
\hline \multirow{2}{*}{$\begin{array}{l}\text { Dist. of Earthq. } \\
\text { Zones Factor }\end{array}$} & Male & 204 & 26,34 & 4,74 & \multirow{2}{*}{617} & \multirow{2}{*}{0,689} & \multirow{2}{*}{0.4} \\
\hline & Female & 415 & 26,09 & 4,15 & & & \\
\hline \multirow{2}{*}{$\begin{array}{c}\text { Effects of } \\
\text { Earthquake Fac. }\end{array}$} & Male & 204 & 29,11 & 4,27 & \multirow{2}{*}{617} & \multirow{2}{*}{$-3,148$} & \multirow{2}{*}{0.0} \\
\hline & Female & 415 & 30,16 & 3,68 & & & \\
\hline \multirow{2}{*}{$\begin{array}{c}\text { Earthquake } \\
\text { Education Factor }\end{array}$} & Male & 204 & 13,77 & 4,61 & \multirow{2}{*}{617} & \multirow{2}{*}{1,026} & \multirow{2}{*}{0.30} \\
\hline & Female & 415 & 13,37 & 4,46 & & & \\
\hline \multirow{2}{*}{ Scale General } & Male & 204 & 69,24 & 9,64 & \multirow{2}{*}{617} & \multirow{2}{*}{$-0,515$} & \multirow{2}{*}{0.60} \\
\hline & Female & 415 & 69,63 & 8,55 & & & \\
\hline
\end{tabular}


Table 7.

ANOVA results related to whether earthquake awareness levels of undergraduate students differ according to students' grade levels

\begin{tabular}{|c|c|c|c|c|c|c|c|c|c|}
\hline Variable & $\begin{array}{c}\text { Levels of } \\
\text { undergraduate }\end{array}$ & $n$ & $\bar{X}$ & SS & $\begin{array}{l}\text { Sum of } \\
\text { Squares }\end{array}$ & df & $\begin{array}{c}\text { Average } \\
\text { squares }\end{array}$ & $\mathrm{F}$ & $p$ \\
\hline \multirow{5}{*}{ 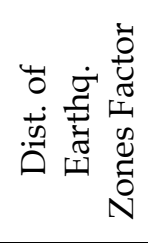 } & 1. grade & 63 & 26,44 & 4,59 & \multirow{5}{*}{113,290} & 3 & \multirow{5}{*}{37,763} & \multirow{5}{*}{2,004} & \multirow{5}{*}{0.11} \\
\hline & 2. grade & 255 & 26,57 & 3,89 & & 615 & & & \\
\hline & 3. grade & 135 & 25,48 & 4,56 & & & & & \\
\hline & 4. grade & 166 & 26,01 & 4,69 & & & & & \\
\hline & Total & 619 & 26,17 & 4,35 & & & & & \\
\hline \multirow{5}{*}{ 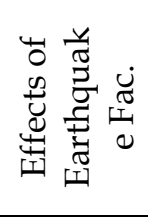 } & 1. grade & 63 & 29,80 & 4,14 & \multirow{5}{*}{20,487} & 3 & \multirow{5}{*}{6,829} & \multirow{5}{*}{0,444} & \multirow{5}{*}{0.72} \\
\hline & 2. grade & 255 & 29,63 & 3,87 & & 615 & & & \\
\hline & 3. grade & 135 & 29,82 & 4,03 & & 618 & & & \\
\hline & 4. grade & 166 & 30,09 & 3,80 & & & & & \\
\hline & Total & 619 & 29,81 & 3,91 & & & & & \\
\hline \multirow{5}{*}{ 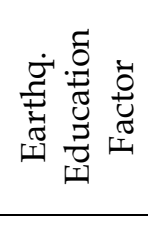 } & 1. grade & 63 & 12,82 & 4,03 & \multirow{5}{*}{112,940} & 3 & \multirow{5}{*}{37,647} & \multirow{5}{*}{1,853} & \multirow{5}{*}{0.13} \\
\hline & 2. grade & 255 & 13,80 & 4,62 & & 615 & & & \\
\hline & 3. grade & 135 & 13,88 & 4,63 & & 618 & & & \\
\hline & 4. grade & 166 & 13,00 & 4,38 & & & & & \\
\hline & Total & 619 & 13,50 & 4,51 & & & & & \\
\hline \multirow{5}{*}{ 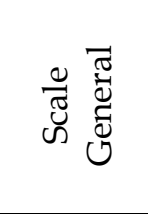 } & 1. grade & 63 & 69,07 & 8,60 & \multirow{5}{*}{115,899} & 3 & \multirow{5}{*}{38,633} & \multirow{5}{*}{0,484} & \multirow{5}{*}{0.69} \\
\hline & 2. grade & 255 & 70,01 & 8,09 & & 615 & & & \\
\hline & 3. grade & 135 & 69,19 & 10,01 & & 618 & & & \\
\hline & 4. grade & 166 & 69,12 & 9,35 & & & & & \\
\hline & Total & 619 & 69,50 & 8,92 & & & & & \\
\hline
\end{tabular}

When Table 7 is examined, one-way analysis of variance (ANOVA) shows whether there is a significant difference between the grade levels and Earthquake Awareness Levels of the students. According to Table 7, there is no statistically significant difference between the distribution of earthquake zones and grade levels among the sub-factors of the earthquake awareness levels of students $[F(3,615)=2,004 ; p>.05]$. There is also no significant difference between the effect of earthquake factor and the students' grade levels $[\mathrm{F}(3,615)=0,444 ; \mathrm{p}>.05]$. There is no significant difference between earthquake education factor, which is the third sub-factor, and grade levels of students $[\mathrm{F}(3,615)=1,853 ; \mathrm{p}>.05]$. There was no significant difference between the overall scale and the students' grade levels $[\mathrm{F}(3,615)=0,484 ; \mathrm{p}>.05]$.

As can be seen in Table 8, the results of one-way ANOVA showing whether there is a significant difference between the residence and earthquake awareness level of the students can be seen. According to the table, there is no statistically significant difference between the knowledge of the distribution of earthquake zones and the residences among the sub-factors of the earthquake awareness levels of the students $[\mathrm{F}(3,615)=1,040 ; \mathrm{p}>$.05]. There is also a significant difference between the second sub-factor, effect of earthquake information factor and students' residences [F $(3,615)=5,022 ; p<.05]$. According to the Tukey test, which is organized at the source of the difference, there is a difference between those staying in the student house and staying with family in favor of staying with family; and those staying in the student house and staying in the state dormitory in favor of the ones who stay at the student house. There is no significant difference between the earthquake education factor, which is the third sub-factor, and the current residence [F $(3,615)=0.163 ; \mathrm{p}>$.05]. There was no significant difference between the overall scale and the current residence $[\mathrm{F}(3,615)=2,054 ; \mathrm{p}>.05]$. 
Table 8.

ANOVA results related to whether earthquake awareness levels of undergraduate students differ according to the residence of the students

\begin{tabular}{|c|c|c|c|c|c|c|c|c|c|c|}
\hline Variable & Residence & $n$ & $\bar{X}$ & SS & $\begin{array}{l}\text { Sum of } \\
\text { Squares }\end{array}$ & $\mathrm{df}$ & $\begin{array}{l}\text { Average } \\
\text { squares }\end{array}$ & $\mathrm{F}$ & $p$ & Tukey \\
\hline \multirow{5}{*}{ 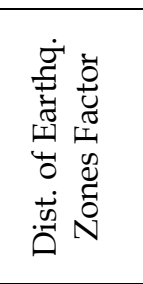 } & $\begin{array}{l}\text { Student } \\
\text { house }\end{array}$ & 131 & 25,90 & 4,32 & \multirow[t]{5}{*}{59,063} & $\begin{array}{c}3 \\
615\end{array}$ & \multirow[t]{5}{*}{19,688} & \multirow[t]{5}{*}{1,040} & \multirow[t]{5}{*}{0.37} & \multirow[t]{5}{*}{-} \\
\hline & Family & 71 & 26,74 & 3,91 & & 618 & & & & \\
\hline & St. dorm & 371 & 26,25 & 4,31 & & & & & & \\
\hline & Pri. dorm & 46 & 25,45 & 5,28 & & & & & & \\
\hline & Total & 619 & 26,17 & 4,35 & & & & & & \\
\hline \multirow{6}{*}{ 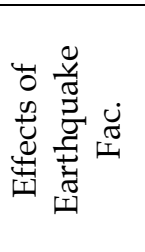 } & Student & & & & \multirow{6}{*}{226,456} & 3 & \multirow{6}{*}{75,485} & \multirow{6}{*}{5,022} & \multirow{6}{*}{0.00} & \multirow{6}{*}{$\begin{array}{l}1-2 \\
1-3\end{array}$} \\
\hline & house & 131 & 28,81 & 4,08 & & 615 & & & & \\
\hline & Family & 71 & 30,91 & 3,42 & & 618 & & & & \\
\hline & St. dorm & 371 & 29,91 & 3,93 & & & & & & \\
\hline & Pri. dorm & 46 & 30,17 & 3,37 & & & & & & \\
\hline & Total & 619 & 29,81 & 3,91 & & & & & & \\
\hline \multirow{5}{*}{ 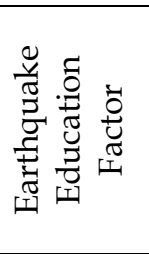 } & $\begin{array}{c}\text { Student } \\
\text { house }\end{array}$ & 131 & 13,56 & 4,52 & \multirow{5}{*}{9,986} & $\begin{array}{c}3 \\
615\end{array}$ & \multirow[t]{5}{*}{3,329} & \multirow{5}{*}{0,163} & \multirow{5}{*}{0.92} & \multirow{5}{*}{-} \\
\hline & Family & 71 & 13,83 & 4,31 & & 618 & & & & \\
\hline & St. dorm & 371 & 13,43 & 4,47 & & & & & & \\
\hline & Pri. dorm & 46 & 13,45 & 5,16 & & & & & & \\
\hline & Total & 619 & 13,50 & 4,51 & & & & & & \\
\hline \multirow{5}{*}{ 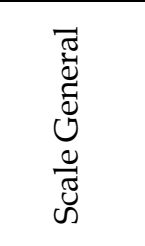 } & Student & 131 & 68,28 & 8,99 & \multirow{5}{*}{488,247} & $\begin{array}{c}3 \\
615\end{array}$ & \multirow{5}{*}{162,749} & \multirow{5}{*}{2,054} & \multirow{5}{*}{0.10} & \multirow{5}{*}{-} \\
\hline & Family & 71 & 71,49 & 8,38 & & 618 & & & & \\
\hline & St. dorm & 371 & 69,60 & 8,98 & & & & & & \\
\hline & Pri. dorm & 46 & 69,08 & 8,68 & & & & & & \\
\hline & Total & 619 & 69,50 & 8,92 & & & & & & \\
\hline
\end{tabular}

Table 9.

ANOVA results on whether the earthquake awareness levels of undergraduate students differ according to the number of floors of the students' residences

\begin{tabular}{|c|c|c|c|c|c|c|c|c|c|}
\hline Variable & $\begin{array}{l}\text { Number of } \\
\text { floor }\end{array}$ & $n$ & $\bar{X}$ & SS & $\begin{array}{l}\text { Sum of } \\
\text { Squares }\end{array}$ & $\mathrm{df}$ & $\begin{array}{l}\text { Average } \\
\text { squares }\end{array}$ & $\mathrm{F}$ & $p$ \\
\hline \multirow{5}{*}{ 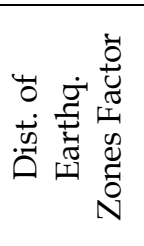 } & 1-2 storey & 66 & 25,83 & 4,68 & \multirow{5}{*}{89,353} & 3 & \multirow{5}{*}{29,784} & \multirow{5}{*}{1,577} & \multirow{5}{*}{0.19} \\
\hline & 3 storeys & 109 & 26,07 & 4,65 & & 615 & & & \\
\hline & 4 storeys & 151 & 25,67 & 4,54 & & 618 & & & \\
\hline & $5+$ stor. & 293 & 26,55 & 4,04 & & & & & \\
\hline & Total & 619 & 26,18 & 4,35 & & & & & \\
\hline \multirow{5}{*}{ 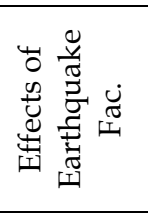 } & 1-2 storey & 66 & 30,26 & 4,20 & \multirow{5}{*}{40,885} & 3 & \multirow{5}{*}{13,628} & \multirow{5}{*}{0,889} & \multirow{5}{*}{0.44} \\
\hline & 3 storeys & 109 & 29,85 & 4,30 & & 615 & & & \\
\hline & 4 storeys & 151 & 29,41 & 3,85 & & 618 & & & \\
\hline & $5+$ stor. & 293 & 29,92 & 3,73 & & & & & \\
\hline & Total & 619 & 29,82 & 3,91 & & & & & \\
\hline \multirow{5}{*}{ 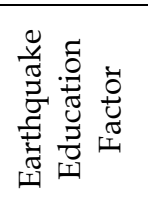 } & 1-2 storey & 66 & 13,32 & 4,53 & \multirow{5}{*}{111,353} & 3 & \multirow{5}{*}{37,118} & \multirow{5}{*}{1,827} & \multirow{5}{*}{0.14} \\
\hline & 3 storeys & 109 & 13,03 & 4,32 & & 615 & & & \\
\hline & 4 storeys & 151 & 13,09 & 4,58 & & 618 & & & \\
\hline & $5+$ stor. & 293 & 13,95 & 4,53 & & & & & \\
\hline & Total & 619 & 13,51 & 4,52 & & & & & \\
\hline \multirow{5}{*}{ 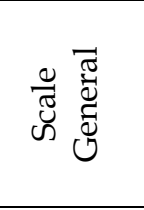 } & 1-2 storey & 66 & 69,41 & 9,78 & \multirow{5}{*}{549,789} & 3 & \multirow{5}{*}{183,263} & \multirow{5}{*}{2,316} & \multirow{5}{*}{0.07} \\
\hline & 3 storeys & 109 & 68,95 & 9,59 & & 615 & & & \\
\hline & 4 storeys & 151 & 68,17 & 8,63 & & 618 & & & \\
\hline & $5+$ stor. & 293 & 70,42 & 8,55 & & & & & \\
\hline & Total & 619 & 69,50 & 8,92 & & & & & \\
\hline
\end{tabular}


When Table 9 is examined, one-way ANOVA results showing whether there is a significant difference between the number of floors and earthquake knowledge levels of the students are observed. According to the table, there is no statistically significant difference in the number of floors of the residence and earthquake knowledge level of the students for the distribution of the earthquake zones factor $[\mathrm{F}(3,615)=1,577 ; \mathrm{p}>.05]$. There is no significant difference between the effect of earthquake factor, which is the second sub-factor, and the number of floors of the students' residence $[\mathrm{F}(3,615)=0,889 ; \mathrm{p}>$.05]. There is no significant difference between earthquake education factor, which is the third sub-factor, and the number of floors of the students' residence $[F(3,615)=1,827 ; p>.05]$. There was no significant difference between the overall scale and the residence of the students $[\mathrm{F}(3,615)=2,316 ; \mathrm{p}>.05]$.

Table 10.

ANOVA results on whether the earthquake awareness levels of undergraduate students differ according to the number of floors of the students' faculties

\begin{tabular}{|c|c|c|c|c|c|c|c|c|c|c|}
\hline Variable & $\begin{array}{c}\text { Fakulty } \\
\text { floors }\end{array}$ & $n$ & $\bar{X}$ & SS & $\begin{array}{l}\text { Sum of } \\
\text { Squares }\end{array}$ & $\mathrm{df}$ & $\begin{array}{c}\text { Average } \\
\text { squares }\end{array}$ & $\mathrm{F}$ & $p$ & Tukey \\
\hline \multirow{4}{*}{ 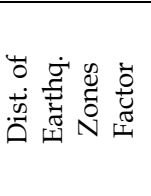 } & 4 storeys & 207 & 26,34 & 3,71 & \multirow{4}{*}{8,355} & 3 & & & & \multirow{4}{*}{-} \\
\hline & 5 storeys & 246 & 26,08 & 4,44 & & 3 & \multirow{3}{*}{4,177} & \multirow{3}{*}{0,220} & \multirow{3}{*}{0.80} & \\
\hline & 6 storeys & 166 & 26,12 & 4,95 & & 615 & & & & \\
\hline & Total & 619 & 26,18 & 4,35 & & 618 & & & & \\
\hline \multirow{4}{*}{ 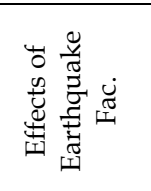 } & 4 storeys & 207 & 29,89 & 3,86 & \multirow{4}{*}{69,140} & 3 & \multirow{4}{*}{34,570} & \multirow{4}{*}{2,265} & \multirow{4}{*}{0.10} & \multirow{4}{*}{-} \\
\hline & 5 storeys & 246 & 30,11 & 3,61 & & 3 & & & & \\
\hline & 6 storeys & 166 & 29,29 & 4,37 & & 615 & & & & \\
\hline & Total & 619 & 29,82 & 3,91 & & 618 & & & & \\
\hline \multirow{4}{*}{ 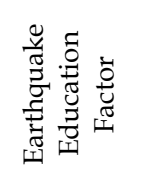 } & 4 storeys & 207 & 14,19 & 4,59 & \multirow{4}{*}{207,987} & 3 & \multirow{4}{*}{103,994} & \multirow{4}{*}{5,167} & \multirow{4}{*}{0.00} & \multirow{4}{*}{$1-2$} \\
\hline & 5 storeys & 246 & 12,85 & 4,39 & & 3 & & & & \\
\hline & 6 storeys & 166 & 13,64 & 4,49 & & 615 & & & & \\
\hline & Total & 619 & 13,51 & 4,52 & & 618 & & & & \\
\hline \multirow{4}{*}{ 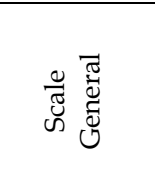 } & 4 storeys & 207 & 70,43 & 8,61 & \multirow{4}{*}{263,865} & 3 & \multirow{4}{*}{131,933} & \multirow{4}{*}{1,660} & \multirow{4}{*}{0.19} & \multirow{4}{*}{ - } \\
\hline & 5 storeys & 246 & 69,04 & 8,52 & & 3 & & & & \\
\hline & 6 storeys & 166 & 69,05 & 9,82 & & 615 & & & & \\
\hline & Total & 619 & 69,50 & 8,92 & & 618 & & & & \\
\hline
\end{tabular}

When Table 10 is examined, one-way analysis of variance (ANOVA) shows whether there is a significant difference between the number of floors of the students' faculties and their earthquake knowledge levels. According to the table, no statistically significant difference was found between the factor of the distribution of earthquake zones and the number of floors of the faculties among the sub-factors of earthquake awareness level $[F(3,615)=0,220 ; p>.05]$. There was no significant difference between the effects of earthquake factor, which is the second sub-factor, and the number of floors of the students' faculties $[\mathrm{F}(3,615)=2,265 ; \mathrm{p}>.05]$. There was a significant difference between the third sub-factor, earthquake education factor, and the number of floors in students' faculties $[F(3,615)=5,167 ; p<.05]$. According to the Tukey test on the source of the difference, there is a difference between four-storey and five-storey faculties and the four-storey faculties are in favor. There was no significant difference between the overall scale and the residence of the students $[F(3,615)=1,660 ; p>.05]$.

When Table 11 is examined, one-way analysis of variance (ANOVA) shows whether there is a significant difference between the faculties and earthquake knowledge levels of the students. According to the table, a statistically significant difference was found between the distribution of earthquake zones factor and the number of floors of the faculties among the sub-factors of earthquake awareness level $[\mathrm{F}(6,612)=3,039 ; \mathrm{p}<.05]$. 
Table 11.

ANOVA results related to whether earthquake awareness levels of undergraduate students differ according to students' faculty types

\begin{tabular}{|c|c|c|c|c|c|c|c|c|c|c|}
\hline Variable & Faculty & $n$ & $\bar{X}$ & SS & $\begin{array}{l}\text { Sum of } \\
\text { Squares }\end{array}$ & $\mathrm{df}$ & $\begin{array}{c}\text { Average } \\
\text { squares }\end{array}$ & $\mathrm{F}$ & $p$ & Tukey \\
\hline \multirow{8}{*}{ 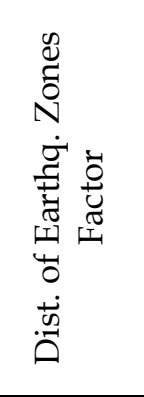 } & Edu. Fac. & 145 & 26,98 & 3,41 & \multirow{8}{*}{338,650} & \multirow{8}{*}{$\begin{array}{c}6 \\
612 \\
618\end{array}$} & \multirow{8}{*}{56,442} & \multirow{8}{*}{3,039} & \multirow{8}{*}{0.00} & \multirow{8}{*}{$1-7$} \\
\hline & Bus. Adm. & 69 & 27,12 & 4,60 & & & & & & \\
\hline & Forestry & 81 & 25,65 & 4,71 & & & & & & \\
\hline & Health S. & 89 & 25,54 & 4,15 & & & & & & \\
\hline & Sci. Lit. & 88 & 25,76 & 4,50 & & & & & & \\
\hline & Relig. & 86 & 26,55 & 5,13 & & & & & & \\
\hline & Engin. & 61 & 24,90 & 4,00 & & & & & & \\
\hline & Total & 619 & 26,18 & 4,35 & & & & & & \\
\hline \multirow{8}{*}{ 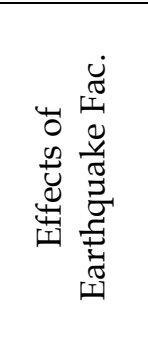 } & Edu. Fac. & 145 & 30,37 & 3,40 & \multirow{8}{*}{295,740} & \multirow{8}{*}{$\begin{array}{c}6 \\
612 \\
618\end{array}$} & \multirow{8}{*}{49,290} & \multirow{8}{*}{3,288} & \multirow{8}{*}{0.00} & \multirow{8}{*}{$\begin{array}{l}2-3 \\
2-7\end{array}$} \\
\hline & Bus. Adm. & 69 & 30,90 & 3,15 & & & & & & \\
\hline & Forestry & 81 & 28,83 & 4,70 & & & & & & \\
\hline & Health S. & 89 & 30,25 & 3,78 & & & & & & \\
\hline & Sci. Lit. & 88 & 29,42 & 3,70 & & & & & & \\
\hline & Relig. & 86 & 29,60 & 4,14 & & & & & & \\
\hline & Engin. & 61 & 28,85 & 4,40 & & & & & & \\
\hline & Total & 619 & 29,82 & 3,91 & & & & & & \\
\hline \multirow{8}{*}{ 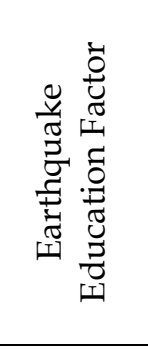 } & Edu. Fac. & 145 & 13,21 & 4,25 & \multirow{8}{*}{831,274} & \multirow{8}{*}{$\begin{array}{c}6 \\
612 \\
618\end{array}$} & \multirow{8}{*}{138,546} & \multirow{8}{*}{7,201} & \multirow{8}{*}{0.00} & \multirow{8}{*}{$\begin{array}{l}1-7 \\
2-7 \\
4-7 \\
5-7 \\
6-7\end{array}$} \\
\hline & Bus. Adm. & 69 & 12,55 & 3,66 & & & & & & \\
\hline & Forestry & 81 & 13,69 & 4,89 & & & & & & \\
\hline & Health S. & 89 & 12,04 & 4,68 & & & & & & \\
\hline & Sci. Lit. & 88 & 13,97 & 4,48 & & & & & & \\
\hline & Relig. & 86 & 13,55 & 4,09 & & & & & & \\
\hline & Engin. & 61 & 16,49 & 4,56 & & & & & & \\
\hline & Total & 619 & 13,51 & 4,52 & & & & & & \\
\hline \multirow{8}{*}{ 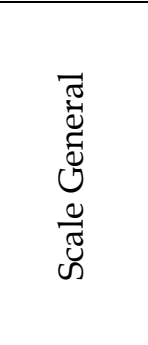 } & Edu. Fac. & 145 & 70,56 & 7,79 & \multirow{8}{*}{679,449} & \multirow{8}{*}{$\begin{array}{c}6 \\
612 \\
618\end{array}$} & \multirow{8}{*}{113,241} & \multirow{8}{*}{1,428} & \multirow{8}{*}{0.20} & \\
\hline & Bus. Adm. & 69 & 70,57 & 7,06 & & & & & & \\
\hline & Forestry & 81 & 68,17 & 10,11 & & & & & & \\
\hline & Health S. & 89 & 67,83 & 8,42 & & & & & & \\
\hline & Sci. Lit. & 88 & 69,15 & 9,55 & & & & & & - \\
\hline & Relig. & 86 & 69,70 & 9,61 & & & & & & \\
\hline & Engin. & 61 & 70,25 & 10,17 & & & & & & \\
\hline & Total & 619 & 69,50 & 8,92 & & & & & & \\
\hline
\end{tabular}

According to the Tukey test on the source of the difference, there is a significant difference between the students of engineering faculty and faculty of education students and the difference is in favor of the students of education faculty. There was a significant difference between the effects of earthquake factor and the students' faculties $[\mathrm{F}(6,612)=3,288 ; \mathrm{p}<.05]$. According to Tukey test on the source of the difference, the difference between the students of the faculty of business administration and the students of the faculty of forestry is in favor of the students of the faculty of business administration. Similarly, there is a significant difference between the students of the faculty of business administration and the students of engineering faculty and it is in favor of the students of faculty of business administration. There is a significant difference between the third sub-factor, earthquake education factor and the students' faculties $[\mathrm{F}(6,612)=7,201 ; \mathrm{p}<.05]$. According to the Tukey test on the source of the difference, there is a significant difference between faculty of education, faculty of business, faculty of forestry, faculty of health sciences, faculty of theology (religious studies), faculty of science and literature, and faculty of engineering. There was no significant difference between the overall scale and faculties $[F(6,612)=1,428$; $\mathrm{p}>$.05]. 


\section{Discussion and Conclusion}

The average of the opinions of the undergraduate students about the distribution of earthquake zones is "I agree" $(\bar{X}=3,73)$, the average of the opinions about effects of earthquake is "I totally agree" $(\bar{X}=4,5)$, the average of opinions about earthquake education is "neutral" $(\bar{X}=2,69)$. According to these data, it can be said that the awareness of undergraduate students about earthquake zones and earthquake effects is enough. These results can be supported with Yildirım and Demirci (2015) and Kaya and Aladağ (2017). According to these results, it can be said that the education of the universities about earthquake is insufficient. Altay (2008) concluded that the subject of earthquake in social studies is not enough. Taymaz (2001) and Ak (2002) found that the training on earthquake at various levels is inadequate.

There was no significant difference between the gender and the distribution of earthquake zones, which is the first sub-factor of earthquake awareness levels, and earthquake education factor of undergraduate students [ $\mathrm{t}(617)=0,689 ; \mathrm{p}>$.05]. It is seen that there is a significant difference in the effect of earthquake factor in terms of gender of students [ $t(617)=-3,148 ; p<.05]$. These results may also be associated with Kayalı (2018) and Aksoy and Sözen (2013). In these studies, gender was accepted as a variable. According to Aksoy and Sözen (2013), there was no significant difference in terms of gender.

There was no significant difference in all sub-factors of undergraduate students' grade levels and earthquake awareness levels of them. Aksoy and Sözen (2013), Kaya and Aladağ (2017), Aydın and Coşkun (2011) also studied on grade levels at various stages and reached similar findings.

In the earthquake awareness of undergraduate students; there was a significant difference in the effects of earthquake factor according to the residence of the students $[F(3,615)=5,022 ; p<.05]$. No significant difference was found in the other sub-factors of the scale in relation to the residence. Aksoy and Sözen (2013) accepted the residence as a variable and there was no significant difference according to residence.

There was no significant difference in the earthquake awareness of the undergraduate students in any sub-factor of the earthquake awareness levels according to the number of floors of the students' residence. Aksoy and Sözen (2013) studied on the number of floors of residences and there was no significant difference in their research.

In the earthquake education sub-factor of the scale regarding the earthquake awareness levels of undergraduate students, a significant difference was found between the four-storey faculty and the five-storey faculty in favor of the four-storey faculty. [F $(6,612)=7,201 ; p<.05]$. In the other sub-factors of the scale, there was no significant difference between the numbers of the floors of the faculties and students' earthquake awareness.

In the earthquake awareness levels of undergraduate students, significant differences were observed in all sub-factors of the scale according to the types of faculties. These differences were mostly in favor of engineering students. Demirci and Yıldırım (2015), Aksoy and Sözen (2013) studied with different types of schools and in Aksoy and Sözen's research (2013) a significant difference was seen according to the type of school.

\subsection{Suggestions}

According to the results of the study, the opinions of the undergraduate students in general indicate that the students are aware of the effects of the earthquake zones and the consequences that the earthquake may have, but the university education is not enough for the preparation of the earthquake. In order to maintain this awareness, it may be suggested to hold trainings and conferences on disasters, especially earthquakes. In addition, it would be beneficial to conduct earthquake evacuation drills in universities and student dormitories. Meeting areas should be identified in these institutions and students should be informed about this. 


\section{References}

Ak, B. (2002). Determination and evaluation of effects of earthquake on school age children's (6-12 years old) behaviours (Unpublished master thesis). Abant İzzet Baysal University, Institute of Social Sciences, Bolu.

Akar, S. (2013). The impact of natural disasters on public finance and macroeconomy: Turkey case. Yönetim ve Ekonomi Araştırmalarn Dergisi, 21, 185-206.

Aksoy B. \& Sözen E. (2013). Evulation of the options of high school students on earthquake training delivered in geography course with different variants (Example of Düzce Province). Uşak Uni. Journal of Social Sciences, 7(1), 279-297.

Altay, S. (2008). Investigating of the topics connected with the earthguake in social sciences lessons in elemantary school (Unpublished master thesis). Abant İzzet Baysal University, Institute of Social Sciences, Bolu.

Arseven, A. D. (2001). Alan araştırma yöntemi (ilkeler teknikler örnekler). Ankara: Gündüz Eğitim Yayıncılık.

Atalay, İ. (1987). Türkiye jeomorfolojisine giriş. İzmir: Ege Üniversitesi Edebiyat Fakültesi Yayıncılık.

Aydın, F. (2010). İlköğretim öğrencilerinin depreme yönelik tutumları. Turkish Studies International Periodical For the Languages, Literature and History of Turkish or Turkic, 5(3),801-817.

Aydın, F. \& Coşkun, M. (2011). Gifted students' opinions about "earthquake": A qualitative study, International Journal of the Physical Sciences 6(7), 1863-1867.

Başıüyük, A. (2004). Yetişkinlerde deprem bilgisi ve etkili faktörlerin incelenmesi. Milli Eğitim Dergisi, 161. online at: http://dhgm.meb.gov.tr/yayimlar/dergiler/Milli_Egitim_Dergisi/161/161-icindekiler.htm

Borg, W. R. \&, Gall, M. D. (1971). Eeducational, research. New York: David McKay Company.

Bozkurt, V. (1999). deprem ve toplum. İstanbul: Alfa Basım Yayın Dağıtım.

Büyüköztürk, Ş. (2018). Manual of data analysis for social sciences (7. press.). Ankara: Pegem Akademi Yayıncilık.

Cross, J. A. (2000). Hazards courses in North American geography programs. Environmental Hazards, 2, 7786.

Demirci, A., \& Yıldırım, S. (2015). İstanbul'da ortaöğretim öğrencilerinin deprem bilincinin değerlendirilmesi. Millî Ĕ̆itim, 207, 89-117.

Demirkaya, H. (2007a). İlköğretim 5. 6. ve 7. sınıf öğrencilerinin depreme yönelik tutumlarının çeşitli değişkenlere göre incelenmesi. Türkiye Sosyal Araştırmalar Dergisi. 11(3), 37-49.

Demirkaya, H. (2007b). İlköğretim öğrencilerinin deprem kavramı algılamaları ve depreme ilişkin görüşleri. Mehmet Akif Ersoy Ĕ̆itim Fakültesi Dergisi, 17(4), 68-76.

Doğanay, H., \& Sever, R. (2016). Genel ve fiziki coğrafya. Ankara :Pegem Akademi Yayıncılık.

Ekiz D. (2015). Bilimsel araştırma yöntemleri. Ankara:Anı Yayıncılık.

Erdoğan, H. (2007). Ortaöğretim coğrafya derslerinde doğal afetler konularının coğrafi bilgi sistemleri uygulamalan ile ögretimi (Unpublished master thesis). Marmara University, Institute of Educational Sciences, İstanbul.

Erinç, S. (2000). Jeomorfoloji-I. İstanbul: Öz Eğitim Yayınları.

Ergünay, O. (1996). Afet yönetimi nedir? Nasıl olmalıdır. Erzincan ve Dinar depremleri ışığında Türkiye'nin deprem sorunlarına çözüm yolları arayışları. In T. Tankut (Ed.), TÜBİTAK Deprem sempozyumu Bildiriler Kitabı (pp. 263-272), Ankara: TÜBITTAK.

Erdik, M. (2002). Earthquake Performance and Vulnerability of Buildings in Turkey. Deprem Mühendisliği Bölümü, Kandilli Rasathanesi ve Deprem Araştırma Enstitüsü, Boğaziçi Üniversitesi, İstanbul.

Erdik, M., Demircioglu, M., Sesetyan, K., Durukal, E. \& Siyahi, B. (2004). Earthquake hazard in Marmara Region, Turkey. Soil Dynamics and Earthquake Engineering, 24, 605-631.

Erkan, S. (2010). A comparative study on the behavioral/emotional problems of preschool children with and without experience of earthquakes. Pamukkale Üniversitesi Eğitim Fakültesi Dergisi, 28(2), 55- 66.

Güngördü, E. (2010). Yer bilimleri. Ankara:Gazi Kitabevi.

Ilgar, R. (2017). Genel fiziki coğrafya: Yer Bilimleri. Ankara:Nobel Yayıncılık.

İzbırak, R. (1991). Yerbilimi bilgileri. İstanbul: M.E.B. Yayınları.

Johnston, D., Tarrant, R., Tipler, K., Coomer, M., Pedersen, S. Ve Garside, R. (2011). Preparing schools for future earthquakes in New Zealand: lessons form an evaluation of a Wellington school exercise. The Australian Journal of Emergency Management, 26(1), 24-30.

Karasar, N. (2016). Scientific research method. Ankara: Nobel Publishing.

Karancı, A.N., Akşit B. \& Sucuoğlu H. (1996). Dinar'da afet yönetiminin psiko-sosyal boyutları. Erzincan ve Dinar depremleri ışı̆̆ında Türkiye' nin deprem sorunlarına çözüm yolları arayışları. In T. Tankut (Ed.), TÜBİTAK Deprem sempozyumu Bildiriler Kitabı (pp. 273-283), Ankara: TÜBİTAK.

Kasapoğlu, A. \& Ecevit M. (2001). Depremin sosyolojik araştırması. Ankara: Sosyoloji Derneği Yayınları, No:8. 
Kaya, B. \& Aladağ, C. (2017). Determining the cognitive structures of geography teacher candidates on "earthquake". International Education Studies, 10(1), 122-136.

Kayalı, H. (2018). A research on the attitude of eight grade students towards earthquake. Educational Research and Reviews, 13(11), 399-405.

Kerski, J.J. (2000). The implementation and effectiveness of Geographic Information Systems Technology and Methods in Secondary Education. University of Colorado, Department of Geography: Colorado.

Kırıkkaya, E. B., Ünver, A. O. \& Çakın, O. (2011). Teachers views on the topic of disaster education at the field on elementary science and technology curriculum. Necatibey Eğitim Fakültesi Elektronik Fen ve Matematik Eğitimi Dergisi, 5(1), 24-42.

Leech, N.L., Barrett, K.C. \& Morgan, G.A. (2005). SPSS for intermediate statistics, use and interpretation (2nd Edition). Makwah: Lawrence Erlbaum Associates Inc.

Lutgens, F. K., Tarbuck, E. J., \& Tasa, D. (2013). Essentials of geology. (Translation Editor: Cahit Helvecı) Ankara: Nobel Academic Publishing.

Moe, T., L., \& Pathranarakul, P. (2006). An integrated approach to natural disaster management: public project management andis critical success factors. Disaster Prevention And Management: An International Journal, 15(3), 396 - 413.

Munich, Re. (2010). Topics: natural catastrophes, annual rewiew of natural catastrophes 2009. Munchen: Munich Re Insurance Company.

Ohnishi, K. \& Mitsuhashi, H. (2013). Geography education challenges regarding disaster mitigation in Japan. Review of International Geographical Education Online, 3(3), 230-240.

Öcal, A. (2005). İlköğretim sosyal bilgiler eğitiminde deprem eğitiminin değerlendirilmesi. Gazi Üniversitesi, Gazi Eğitim Fakültesi Dergisi, 25(1), 169-184.

Özdemir, Ü., Ertürk, M., Güner, İ., \& Koca, M. K. (2001). İlköğretimde deprem ve depremin zararlarından korunma yollarının önemi. Doğu Coğrafya Dergisi, 7(5), 109-131.

Öztürk, S., Bayrak, Y., Çınar, H., Koravos G.C. \& Tsapanos, T. M. (2008). A quantitative appraisal of earthquake hazard parameters computed from Gumbel I method for different regions in and around Turkey. Natural Hazards, 47, 471-495.

Panic, M., Kovaceiıc-Majkic, J., Miljanovic, D. \& Miletıc, R. (2013). Importance of natural disaster education - Case study of the earthquake near the city of Kraljevo. J. Geogr. Inst. Cvijic, 63(1), 75-88.

Pelling, M. Özerdem, A. \& Barakat, S. (2002) The Macro-Economic Impact of Disaster. Progress in Development Studies, 2(4) 283-305.

Ross, K. E. K. \& Shuell T. J. (1993). Children's beliefs about earthquakes. Science Education, 77(2), 191-205.

Schermelleh-Engel, K., Keith, N., Moosbrugger, H., \& Hodapp, V. (2004). Decomposing person and occasion-spe- cific effects: An extension of latent state-trait theory to hierar- chical LST models. Psychological Methods, 9, 198-219.

Sert, E. (2002). The Influence level of the earthquake on the motive and succes and feulure of the primary school students (Unpublished master thesis). Sakarya University, Institute of Social Sciences, Sakarya.

Şahin, C., \& Sipahioğlu, Ş. (2007). Doğal afetler ve Türkiye. Ankara: Gündüz Eğitim Yayıncllı.

Şencan, H. (2005). Reliability and validity in social and behavioral measurements. Ankara: Seçkin Publishing.

Şimşek, C. L. (2007). Children's ideas about earthquakes. Journal of Environmental \& Science Education, 2(1), 14-19.

Tanaka, K. (2005). The impact of disaster education on public preparation and mitigation for Earthquakes: a cross-country comparison between Fukui, Japan and the San Francisco Bay Area, California, USA. Applied Geography 25, 201-225.

Taş, G. (2003). Türkiye'de ortaöğretim kurumlarında doğal afetler (Deprem, kütle hareketleri, volkan, don olayı) konularının öğretiminin değerlendirilmesi. (Unpublished master thesis). Gazi University, Institute of Educational Sciences, Ankara.

Tavşancıl, E. (2005). Measurement of attitudes and Data analysis with SPSS. Ankara: Nobel Publishing.

Taymaz, M. (2001). Doğal afet zararlarını azaltma çalışmaları. Afet Dergisi, 1(2), 4-5.

Tsai, C. C. (2001). Ideas about earthquakes after experiencing a natural disaster in taiwan: an analysis of students' worldviews. International Journal of Science Education, 23(10), 1007-1016.

TÜBİTAK. (2001). 17 Ağustos 1999 depremi sonrası Düzce İlçesi alternatif yerleşim alanlarının jeolojik incelemesi. Ankara:TÜBITAK

Vance, K., Miller, K., \& Hand, B. (1995). Two constructivist approaches to teaching ecology at the middle school level. The American Biology Teacher, 57(4), 244-249.

Yazıcı, H. \& Koca, N. (2014). Türkiye coğrafyası ve jeopolitiğì. Ankara:Pegem Akademi Yayıncılık. 
Yıldız, M. (2000). İlköğretim okullarındaki öğretmenlerin deprem öncesinde ve deprem sonrası öğrenme ve öğretme başarıları ile deprem sonrası oluşabilecek değişiklikler. (Unpublished master thesis). Marmara University, Institute of Educational Sciences, İstanbul. 